\title{
Introduction: The Problem and Its Context
}

Maids are the thing to have, according to a journalist commenting on the unexpected response to the "Win a Maid" contest launched in January 1986 by Family Circle, an American magazine with a huge readership among mainstream women. When the magazine editor in charge of the contest returned after a two-week vacation, her office was filled with boxes and bags of mail entries to the contest. ${ }^{1}$ At the end of March 1986, a weekend magazine accompanying one of Chicago's Sunday papers featured a sweepstakes contest sponsored by a company specializing in household cleaning aids; it offered free maid service once a week for a year as the grand prize. Illustrating the contest rules was a photograph of the face of a woman in a maid's uniform, with lace cap and collar and a willing smile, along with cleaning aids, mop, and broom. ${ }^{2}$

It is in such notices, as well as in the growing number of classified newspaper advertisements placed by women willing to hire out their labor for household work as housekeepers, cleaners, cooks, and childminders, or combinations of these, that the late-twentieth-century face of domestic

1. Bob Greene, "A Contest Tailor-Maid for Today's Woman," Chicago Tribune, January 27,1986 , sec. 4 , p. 1.

2. Chicago Tribune, Weekend Magazine, March 21-23, 1986, end page. This was not a unique incident but part of a pattern that indicates how commercial interests are attuning themselves to their customers' needs and desires. Among others of the same kind, Tanqueray, the English gin bottlers, launched a sweepstakes with the prize of an "English butler for a season or $\$ 25,000 "$ in Courmet, May 1986, p. 29 , and Rubbermaid, a kitchen-gadget firm, featured a "win-a-maid-for-a-year sweepstakes," worth $\$ 2,500$ in cash in the New York Times Magazine, part 2, Good Health, March 29, 1987, p. 45. 


\section{Introduction}

service in America comes clearly into focus. ${ }^{3}$ These observations command us to question the long-held sociological assumption that paid household work has all but disappeared in contemporary Western society. And in several developing countries such as Zambia, the growth of domestic service as a segment of the wage labor force prompts additional questions concerning its predicted decline in the course of the industrialization process. Taken together, these two sets of observations invite us to reconsider the comparative dynamics of paid household work, its relation to wider economic processes and their shifts both at home and abroad; its changing faces, that is, different labor forms such as live-in and day work; the nature of the work done in private households; gender differences in the labor process; and of the consequences of all of these factors for the private lives of servants and their employers.

A good place to start exploring these questions is Zambia, a developing country in the southern part of the African continent, the geographical locus for this work. If the contests described above strike a nerve among American women, so they would in Zambia, which has only in recent years emerged from its former colonial status. The great majority of servants in the past were men as they are today, although women have entered this occupation, particularly as nannies, in growing numbers since independence. Domestic service is not "naturally" women's work everywhere, and certainly not in Zambia. There, the question of servants is of crucial concern to madams (as female employers of servants invariably are called in southern Africa), for many of the same reasons - and for some different ones-as in the United states.

During the colonial period in what was then known as Northern Rhodesia and also since 1964 in independent Zambia, servants were and are a sine qua non of social and economic position, yet their white employers considered them problematic and their chiefly Zambian employers today still do so. The colonial period's unequal master-servant relationship used race to distance domestics from employers. The lack of postcolonial economic development in Zambia has accentuated the opportunity gap between servants and employers. A changed relationship of distance has emerged in domestic service in which the colonial era's racial distinctions have been replaced by class-based ones. In comparison, during the expansion of the United States' economy in the early decades of this century, white female immigrant live-in domestics found better jobs and left the occupation to minority, especially black, women and, lately, to new female immigrants often of Third World origin who now largely do day work. More recent economic transitions and the growing need for families to have

3. This statement is based on my observation of the classified columns of "household help, wanted" and "situation wanted" in the Chicago Tribune from January 1986 through May 1987. 
dual wage earners have increased the need for domestic help, which is proliferating in many forms-live-in, day work, and commercial contracting. These changed economic developments are creating a new class of domestic workers in the United States whose relationship to employers is characterized by inequality. While the evolving story of domestic service in Zambia provides an important study in its own right, it offers a comparative case that casts critical light on our own situation. Rapidly changing economies, the different, and changing, roles of men and women in paid and unpaid household work, and a growing class gap between poverty and wealth come into play in both Zambia and the United States in the mid-1980s. This situation was not anticipated by conventional sociological wisdom and it requires new thinking.

In this book I describe and analyze continuities and changes in domestic service in Zambia from 1900 to 1985 by a retrospective examination of how the world of domestic servitude was created, maintained, sometimes changed, and at times resisted as a result of the interaction between servants and their employers, both men and women. I also seek to capture how that changing world was experienced in the everyday lives of servants and employers; how their relationships with members of their own households and others in the wider society shaped this peculiar world of work; and how the world beyond the household as a work locus at times was affected by servants' activities. Good household management revolved around strictly upheld distinctions between the servant and the employer, and it also turned on sexual criteria. Human-made distinctions, construed as essential difference in culture, race, class, and sex, turned the servant's personhood in otherness, and the changing construction of difference is a central concern throughout this book.

Why write a book about an occupational domain that according to conventional sociological wisdom has been considered to be obsolete in contemporary society? ? $^{4}$ That belief was based on a limited number of studies, conducted mainly in northwestern Europe and North America, which described changes in domestic service as involving a transition from male to female by the end of the 1700 s, and its remaining women's main source of urban wage income till the second or third decade of the present century, when wage-labor opportunities opened up in new fields. ${ }^{5}$ In the wake of

4. Lewis A. Coser, "Servants: The Obsolescence of an Occupational Role," Social Forces 52 (1973): $31-40$.

5. For standard description and analysis of this scenario, see, e.g., Vilhelm Aubert, "The Housemaid-An Occupational Role in Crisis," Acta Sociologica 1 (1955-1956): 149-158; Pamela Horn, The Rise and Fall of the Victorian Servant (New York: St. Martin's Press, 1975); and Theresa McBride, The Domestic Revolution: The Modernization of Household Service in England and France, 1820-1920 (London: Croom Helm, 1976). 
that process the time-honored species of the genus servant, the live-in domestic, supposedly disappeared. Extrapolations from this pattern of near certainty were extended to the developing world with the suggestion that a similar process would occur there. ${ }^{6}$

This thinking has died hard for a number of reasons. One has to do with the lack of serious scholarly attention given to this occupation in the West and elsewhere. An occupational domain that for two centuries or more had been the single largest wage employment avenue for women remained largely forgotten. In the scholarship on the developing countries, the working lives of domestic servants were barely explored, in spite of the fact that paid domestic service often provided one of the earliest means to incorporate subject peoples into a newly created world of wage labor. Miners, railway workers, and traders in the markets were perhaps more conspicuous, and certainly more often targets for study. ${ }^{7}$

Another reason concerns the unilinear assumptions of modernization theory that have influenced our thinking about development. They center around ideas of convergence of the economic development path in the industrial world and newly industrializing countries. Modernization theory has not held up well in the face of the actual development experience in most parts of the Third World. And advanced capitalism at home has not been accompanied by the expected promethean industrial expansion. Rather, the old manufacturing structures are crumbling as the West is undergoing partial deindustrialization and transnational corporations locate manufacturing plants in Third World countries, in an overall process that is shaping a new international division of labor ${ }^{8}$ In the course of this transformation process, the composition of the Western wage labor force is changing, not only by sector, but also by sex. The manufacturing sector is shrinking while employment in service industries and service-oriented work is on the rise. The opportunity gap is widening. Today in the United States women of better and worse means are meeting in contractual employment relationships centered on household and child care which are recasting the live-in domestic service relationship of a previous era into new labor forms.

6. David Chaplin, "Domestic Service and Industrialization," Comparative Studies in Sociology I (1978): 97-127.

7. For an overview of prominent topics and themes in the study of African labor history, see Bill Freund, "Labor and Labor History in Africa: A Review of the Literature," African Studies Review 27 (1984): 1-58.

8. Folker Fröbel, Jürgen Heinrichs, and Otto Kreye, The New International Division of Labour: Structural Unemployment in Industrialised Countries and Industrialisation in Developing Countries (Cambridge: Cambridge University Press, 1980), provides a general statement on this emerging process. Special attention to gender in this process is offered in June Nash and Maria Patricia Fernandez Kelly, eds., Women, Men, and the International Division of Labor (Albany: State University of New York Press, 1983). 
Far from having disappeared, one labor form of domestic service, namely day work, undertaken by workers who live out, appears to be growing.

The processes outlined above are not so far removed from Zambia as they might appear. Economic opportunities among all population segments in that country are linked subordinately to developments in the West. While Zambia is not hosting any global industry for assembly of Western manufactured parts for export to the West, it is intimately linked to world market ups and downs through exports of its chief source of revenue, copper. Aside from mining, there is little local industry or manufacture, and what little there is depends heavily on imported raw materials. When the downturn in the world economy of the early 1970s hit Zambia, the economy stagnated and overall employment shrank. Yet within this decline, the domestic service sector and the government sector have continued to grow. Rapid urbanization with one of the highest rates in Africa, if not the Third World, daily adds new potential workers to a labor force, of whom fewer and fewer find wage work. The opportunity structure has become markedly skewed and the gap between poor and rich is widening. ${ }^{9}$ With it, new distinctions are being forged between fellow citizens as more and more black Zambians go to work as servants for black Zambian employers. As a result of the postcolonial indigenization of the economy, more Zambians than ever before work in middle- and upper-level positions in government, parastatal companies, and in the few remaining private firms. Clerking, teaching, and nursing jobs are held increasingly by Zambian women. These households account for the growth since independence in 1964 of the servant-employing class. They, the new expatriates, and the remaining old-timers of white or Asian background all employ servants.

Women in Zambia want household help. Not maids, but male servants, for their preferred servant is a man. They have few positive remarks to make about women servants, who are relatively recent entrants to this particular segment of the labor force. Today, paid domestic service is not gender-typed as woman's work everywhere, nor was it so historically. The Zambian case allows me to question the application of a biological metaphor in accounts of the social relations in domestic service which stress the occupation's function as a "natural" extension of women's reproductive role. Gender roles are not given; they are made. Their construction depends on a complex interweaving of cultural factors and social practices with economic forces and questions of power, and their unraveling is central to this book.

9. For analysis of recent socioeconomic conditions in Zambia, see Cherry Gertzel, ed., The Dynamics of the One-Party State in Zambia (Manchester: Manchester University Press, 1984). 


\section{Introduction}

I set about the task of describing the empirical processes that affect servants and their employers by approaching domestic service at several different, sometimes overlapping, levels of analysis, linking cultural, demographic, and labor market factors over time. I seek to incorporate a sense of history, and I aim throughout to capture how servants and their employers experienced their unequal companionship in a changing world in a way that brings life to their world. My concerns are with changes in the nature of the servant-employer relationship, with special attention to differences in the labor process depending on whether the servant is a woman or a man; with changes in the type of work that is carried out in private households; with the effects that the work of a domestic has on the servant's own household and-off-the-job activities, and the ways in which such social practices in turn affect the job situation; with the structure of the labor force in domestic service, over time and in relation to overall employment patterns, and by sex. I am also concerned with the changing relationship among domestic servants, and between them and other workers - that is to say, with the questions of whether or not-and, if so, when-they constitute a class in terms of objective indicators as well as of felt identity of interests. The final issue I explore concerns the broader dynamics in paid household work between a developing country like Zambia and a Western country, such as the United States. In that effort, I seek to bring my findings from Zambia to bear on developments closer to home, and ultimately on the task of throwing light on the place of paid household work in the changing economic context of advanced capitalism.

\section{The Problem of Domestic Service}

But why domestic service? What's the study for, anyway? as some of the people I interviewed asked when I approached them in Lusaka, Zambia's capital, between 1983 and 1985. There is more to this than culture, demography, and labor market factors in Zambia, although these factors all bear upon it in complex ways. I wish to stress that the at times fascinating, yet mostly depressing, story of domestic service in Zambia speaks to larger issues. As I hinted at before, some of these issues concern inequalities in opportunity and income-in short, class-which prompted the creation of and fuels today's reproduction of a dependent, subordinate labor formpaid domestic service - in various disguises across time and space. Its continued existence is not to be understood as an archaic remnant of the early phases of capitalist development. Vast present-day income gaps coupled with distinctions in consumption styles are central to the production of domestic service, which in turn plays a focal role in reproducing these distinctions. Because of this double centrality, domestic service is a key 


\section{Introduction}

occupational domain to study for purposes of clarifying the mediation of poverty and wealth which takes place in the encounter across the private household's class chasm beyond the factory gates and the office, and is so intimately linked to developments in these institutions.

The comments just made may read as if the larger issues in this study are revealed merely by attributing an economic function to domestic service: it reproduces class privilege. Such an explanation might perhaps work, if made on the basis of aggregate statistical data and national input-output statistics. But it would tell us little about the making of this particular labor form. Nor would it tell us how the relation sometimes was resisted, at times changed if not transformed, yet reproduced over time into one or several simultaneously existing forms of paid domestic labor. And the explanation would leave out completely any understanding of this occupational domain as a created world of labor, a product of the lived and changing experiences of women and men, servants and employers, as well as other members of the society of which they are all part.

The larger issues of this book, then, revolve around inequality, and specifically what it has meant and how it has been experienced in the relationship between men and women servants and their employers from different generations and of various cultural, national, or ethnic backgrounds, from about the turn of the century through the mid-1980s in Zambia. Inequality is at the core of their relationship. It is the basis that structures the labor process and informs the asymmetrical encounters between the chief actors in domestic service-servants and employerswhose created places are construed as belonging to distinctly different worlds. Domestic service, I claim, at least in the live-in version I set out to trace retrospectively in Zambia, and perhaps as well under conditions of day work, can only operate smoothly in situations where servants and employers are considered different from each other. These differences are constructed and informed by essentialist notions of race, culture, sexuality and class. Highlighted differentially, but not incidentally, across time and space, these differences mask, at least temporarily, the co-presence and participation of servant and employer in a shared world.

This paradox of conspicuous presence and social invisibility first struck me when I stayed with Danish relatives in Nairobi before traveling upcountry on my first stint of fieldwork as an undergraduate in 1969. I grew up in a society permeated by egalitarian values and in a home free of any gender- and aged-based hierarchy. My father died when I was five years old, and my mother, then forty-eight, went back to work to support her household of three girls and one boy aged between five and seventeen. There was never any question of women not doing things on their own, for we had to. Our participation and initiatives were counted on, and our presence acknowledged. And there were no authoritarian restrictions placed to 
limit our ambitions. My reaction in Nairobi was one of distinct dislike of what I experienced as the awkward presence of the paid hand who was regarded more as a thing than a person. This experience repeated itself in 1971 when I began my first of several research periods in Zambia, whenever I stayed in a servant-keeping household. Although my research over the years has taken me into Lusaka's low-income areas, where I have tried to clarify the forces that influence women's work in the home, yard, market, and city, I remain puzzled and troubled by the deeply sedimented weight of domestic service, which it seems to me most people in Zambia take for granted.

As an anthropologist socialized in a nonhierarchical setting who has had to study about different societies and social structures around the world, I have been made to understand that some societies are structured by ideologies of inequality which place distinct groups of people in asymmetrical relationships of domination and subordination. India, for one, is often referred to as a society in which people accept inequality, rather than question it. ${ }^{10}$ With the anthropologist's conventional stance of cultural relativism, I ought perhaps to have viewed servant-employer relationships in Zambia from that perspective. Given the two sides' interdependence, here was a relationship that, in the language of cultural relativism, could be seen as benefiting all. Yet my problem, and the problematic and troublesome persistence of domestic service, was not an archaic or paternal one. Old habits of domestic service had not been broken, servants had not acquired many marketable skills from life-long work in private households, nor had they been able to create new lives. The problem in nonacademic terms was that the relationship in practice made exploitation almost inevitable. The colonial era's authoritarian tradition of white men's mastery over subject races who lived and worked in fear of coercive rules and regulations had not so much disappeared as been transformed, into a kind of servitude that both servants and their employers find troublesome and would rather not be part of, were the economic situation different. To understand this, cultural relativism is of no use.

\section{The Making of Difference}

My choice of terms in the preceding discussion implies certain conceptual and theoretical assumptions. I am influenced by the recent rapprochement between history and some branches of anthropology and the other social sciences. ${ }^{11}$ This influence is reflected in my concern to explore and

10. Louis Dumont, "Caste, Racism, and Stratification: Reflections of a Social Scientist," Contributions to Indian Sociology 5 (1961): 20-43.

11. This rapprochement is particularly evident in interdisciplinary studies of social history, family history, labor history, and popular culture. It draws inspiration from, among others, 
explain the dynamics of change within domestic service as well as to account for the causal relationship between shifts in domestic service and changes of more macrolevel forces. I do so in a processual sense, recognizing that although societal structures and their development in many ways restrain and limit local-level activity, individuals are more than cogs in wheels. They are human social actors who are aware of the constraints on their activity and who through conscious interaction and goal-directed activity are centrally involved both in making the world of which they are part and in changing it. ${ }^{12}$ Given this orientation, I seek to attribute to servants a sense of life and agency and to highlight their role in some of the far-ranging changes that have affected and are transforming their society. And, I suggest that the lack of attention historians and anthropologists have paid to this particular social and economic domain in part reflects the limits of explanatory frames that ignore the individual as a human agent. In more ways than one, the previous generation's scholarly community reacted like most employers of servants: they took them for granted.

The attitude of taking servants for granted touches a central nerve in the making of difference. The unequal relationship across the private household's class divide is maintained through practical arrangements that create distance between the chief actors. Unequal distribution of economic means and differential access to power underpin the relationship whose tenuous balance is threatened once personality and affect become implicated in day-to-day interaction. The conceptual and theoretical problem at stake here is the making of difference, conceived in a manner that has implications quite unlike the we/they distinctions often drawn in the books on race relations a generation or so ago. ${ }^{13}$ The basis of this distinction was taken for granted and the questions that were asked concerned the functional ramifications of race relations in society.

The construction of difference has been an object of recent literary work, some observations from which I wish to adopt in this study. Edward Said's work of literary criticism, Orientalism, describes the creation of the Orient and Orientalism as a European invention. ${ }^{14}$ Disregarding local social and cultural complexity, a notion of Orientalism emerged in literature which had less to do with the real Orient and its peoples as free subjects of

the historical work of Eric Hobsbawm and E. P. Thompson, the sociological work of Anthony Giddens, and the anthropological work of Pierre Bourdieu. For a discussion of this trend, see the contributions to "Anthropology and History in the 1980s," Journal of Interdisciplinary History 12 (1981): 227-275.

12. This, of course, was the important message of $\mathrm{E}$. P. Thompson's The Making of the English Working Class (London: Gollancz, 1963).

13. See, for example, Peter I. Rose, They and We: Racial and Ethnic Relations in the United States (New York: Random House, 1974).

14. Edward W. Said, Orientalism (Harmondsworth: Penguin Books, 1985). 


\section{Introduction}

thought and action than with the idea of Europe as superior compared with all non-European peoples and cultures. Said discussed and analyzed Orientalism as "the corporate institution for dealing with the Orient-dealing with it by making statements about it, authorizing views of it, describing it, settling it, ruling over it: in short, Orientalism as a Western style for dominating, restructuring and having authority over the Orient." 15 For its strategy, Orientalism manufactures new differences out of what is a manifestly different, or alternative and novel, world. In this, it makes use of a sense of "positional superiority, which puts the Westerner in a whole series of possible relationships with the Orient without ever losing him the relative upper hand." 16

In Africa, at least till fairly recently, Europeans saw blacks as fit only for domination. ${ }^{17}$ They viewed blacks through a lens of contrasts and were struck by how different Africans were from themselves: in terms of skin color certainly, by not being Christian, and because of social and political arrangements very unlike those in Europe; worse still, they lived on vast, unexplored, wild lands they did little to harness for productive purposes. Many elements of these early views remained embedded in the discourse that, at the level of officialdom as well as in private households, came to structure the relationship between whites in dominant positions and their black subjects throughout the colonial period-although the relative emphasis on each element did shift over time, and might perhaps vary, depending on who did the colonizing. ${ }^{18}$

My excursion into the realm of literary discourse is not a detour; it strikes at the core question of how difference becomes structured, and why it takes its particular shape. For it is not only literary writers or professional anthropologists, who view the other as different and removed from the self in space and time. ${ }^{19}$ Ordinary people do so; the colonialists did it, as did the servants in Northern Rhodesia. Servants and their employers in postcolonial Zambia continue to do so, as we ourselves do in the West, construing difference and otherness in such class or classlike terms as subculture, culture of poverty, and underclass, to mention just a few of recent prominence in the United States. Regardless of progress in society,

15. Ibid., p. 3.

16. Ibid., p. 7.

17. For the literary construction of the African on French terms, see Christopher L. Miller, Blank Darkness: Africanist Discourse in French (Chicago: University of Chicago Press, 1985).

18. For the French, see William B. Cohen, The French Encounter with Africans: White Response to Blacks, 1530-1880 (Bloomington: Indiana University Press, 1980). Early British attitudes are described by H. Alan C. Cairns, Prelude to Imperialism: British Reactions to Central African Society, 1840-1890 (London: Routledge and Kegan Paul, 1965).

19. Johannes Fabian, Time and the Other: How Anthropology Makes Its Object (New York: Columbia University Press, 1983). 
unequal gender relations continue too often to be accounted for in terms of difference, that is, essentialist sexual notions. But difference or otherness is a multifaceted phenomenon. ${ }^{20}$ When implicated in creating the boundary between the black manservant and his white employer within the colonial household in Zambia, difference stood for the complex interaction of race and culture which then connoted civilization. When servants made trouble and employers complained about their unpredictable behavior, they would refer to their servants' strange customs and tribal mores. Under the thin surface of acquired household mores always lurked the essential African, that is, the primitive. When it came to women servants, trouble was attributed to immorality and promiscuity, that is, essential sexuality. Today's servants continue to make life difficult for their employers. Their Zambian bosses see menservants as members of another class whose needs and problems are quite unlike their own and whom they therefore can treat differently. Regarding their problems with women servants, employers are still less neutral in identifying the difference that matters: sexuality. For women are said to be less tractable than menservants because of their struggle either to get rid of or to find a husband and/or lover. Domestic service in Zambia was, and still is, structured around the making and remaking of differences.

\section{The Power of Dufference}

In order to relate issues of class and power to the construction of difference I need to draw on additional explanatory insights and situate what looks like an island unto itself-the private household with its purposefully interacting agents-within the wider society of which it is a part, so that activity at each level may be understood to have bearing on the other. Domestic service is not quite a total institution in Erving Goffman's terms. ${ }^{21}$ It is an open-door institution from which inmates have several exits, which have varied over time and differed to some degree, depending on the political, economic, and cultural setup of the surrounding society. These open doors all influence what goes on in the household between servant and employer, but differentially so. The difference results from the participants' unequal power, which enables the employer to issue commands more often than the servant can choose not to obey. Said's notion of positional superiority is relevant here, as is the version of power formulated by Anthony Giddens. ${ }^{22}$

20. See contributions to the special issue "'Race,' Writing, and Difference," Critical Inquiry 12 (1985).

21. Erving Goffman, Asylums (Garden City, N.Y.: Doubleday Anchor, 1961).

22. Anthony Giddens, Central Problems in Social Theory: Action, Structure, and Contradiction in Social Analysis (Berkeley: University of California Press, 1979). 


\section{Introduction}

Many of Giddens's concerns - the conscious actor, intentional activity and its central role in the reproduction and change of society-are shared by others. ${ }^{23}$ Fredrik Barth, for example, has discussed how intentionality leads to institutionalization, and Pierre Bourdieu how practice becomes habitus. ${ }^{24}$ These concepts, however, neither analyze the effects of time nor do they explain how power becomes an element of action. Michel Foucault sees modalities of power everywhere, but in an evocative rather than analytical way. ${ }^{25}$ But Giddens's framework does more than invoke such notions: it provides a way of analyzing them.

In his attempt to incorporate the relationship between human agency and structure into social theory, Giddens develops the notion of structure as process, which he gives the aptly descriptive name of structuration. The informal rules people devise in their day-to-day conduct are in his framework thought of as social practices that constitute the structuring properties implicated in the reproduction of social institutions. These structuring properties are both the media and the outcome of interaction: they enable as well as constrain. This twofold aspect of interaction produces what Giddens speaks of as the duality of structure. ${ }^{26}$ Power is an integral part of this process, for it refers to transformative capacity. Instantiated in action as a regular and routine phenomenon, it relates to rules and resources, though in itself power is not a resource in this framework. Rather, "resources are the media through which power is exercised, and structures of domination reproduced." 27 Power, in matter-of-fact words, is a means of getting things done as well as of choosing not to do them. It refers to relations of autonomy and dependence in interaction, to the capability of actors to get others to comply with their wants.

Because power is a two-way relationship, servants in Zambia retain some autonomy even though they are dependent actors in relation to employers in the household situation. This power is exemplified in their choice not to do, or to perform in their own way, the orders an employer issues. Although the employer is the more autonomous actor owing to the more effective means of compliance at his or her command-that is, the capacity to sack, to withold pay, and not to provide references or to provide bad ones-he or she is in some degree dependent on the servant. Using the

23. Sherry B. Ortner, "Theory in Anthropology since the Sixties," Comparative Studies in Society and History 26 (1984): 126-165.

24. Fredrik Barth, "Models of Social Organization," Royal Anthropological Institute, Occasional Paper, no. 23 (1966); Pierre Bourdieu, Outline of a Theory of Practice (Cambridge: Cambridge University Press, 1977).

25. Michel Foucault, Power/Knowledge: Selected Interviews and Other Writings, 19721977, ed. Colin Gordon (Hassocks: Harvester Press, 1980).

26. Giddens, Central Problems, pp. 69-78.

27. Ibid., p. 91. 
discourse of servants, the decision not to obey, or to do things his or her way, is a response to "too much work" and to the employer's "talking too much" or "too loud." Servants pursue such practices with the practical knowledge that household work never stops. For once one task is done, others will be issued. The employers say that "orders have to be repeated all the time" and that "sevants are lazy"; they "never learn," and to be sure "they're different!" By repeating orders, the employer adjusts his social practice to the conduct of the servant, who thus retains some power in structuring the household situation and in a way that affects how both servant and employer are getting things done over time as their activity unfolds in space.

This simple example of Giddens's duality of structure at work, chosen from many to be discussed in the body of this work, shows us conscious agents par excellence. The social practices they use in their interaction help to create and reproduce the informal rules that structure their interaction as well as the resources they draw on differentially. In the course of doing so, servants and employers monitor each other's conduct reflexively. Their mutual monotoring is influenced by two levels of consciousness, according to Giddens: "discursive" and "practical." 28 Discursive consciousness refers to peoples' capacity to "give reasons" and "rationalize" their conduct; practical consciousness, to the "stocks of unarticulated knowledge" people use implicitly to orient themselves to situations and when interpreting the acts of others. What servants and employers say about each other involves both these levels.

Servants and employers find their institution hard to understand in discursive terms; but each of them knows, in a practical sense, a great deal about its workings because they participate in it. What they say about each other does not constitute a description or explanation of their relationship. Rather, their statements about each other are part of that relationship, helping them to define each other. ${ }^{29}$ Incorporating into my analysis the sometimes contradictory concepts that employers and servants use about each other will, I suggest, throw fresh light on the domestic service institution and present it in a way that reckons with human agency and is not static.

In their mutual monitoring when interacting in the household, servants and employers make use of social practices that become predictable and stable over time. These practices develop into routines, which in turn become patterned in space, that is to say, they become institutionalized. The rules and resources both parties draw on in their routines can be recombined into different forms, changed, and new ones can be created

28. Ibid., pp. 24-25.

29. Ibid., pp. 248-253. 


\section{Introduction}

from scratch. ${ }^{30}$ These techniques, which are contained in the stocks of servants' and employers' practical consciousness, help to reproduce their interaction through time and affect the way relationships are ordered across space. ${ }^{31}$ Notions that servants and employers have of each other as being different underpin this structuration.

\section{The Difference Class Makes}

The employers' power over servants results from their control of resources which they can bring to bear on the work situation to effect their servants' compliance. This control is a result of their advantaged position in society in class terms, at least when compared with the servants, who have nothing to sell but manual-labor power. Few servants in Zambia today have even seven years of schooling, whereas most of the persons who employ them have at least high-school education. Far from all being in professional jobs or holding executive positions, the majority of employers are on government payroll. Even the least affluent of employers have regular monthly incomes (sometimes earned by both spouses) which facilitate access to class privilege - the means by which the difference between servant and employer, is made and re-created.

Class in this book is defined in Marx's terms: by relation to the means of production. It has an objective and a subjective face. The problem that besets its discussion is that although we as observers can readily identify class in terms of objective indicators, people themselves do not always share an identity of felt interests in such broad terms. ${ }^{32}$ Most of the world's history shows us that in fact they have rarely done so. Race, ethnicity, and gender complicate the question, as does a variety of sectional interests. Racial segregation, minority status in ethnic and gender terms, cultural practices, and religious prescriptions among others, singly or combined, can affect how a person experiences his or her world as a worker. It is with the unfolding of such experiences that I am concerned here: how servants' experiences have been shaped by broader economic forces in the surrounding society if not the wider world, by the labor process within domestic service, and by social practices that take place beyond the work locus. With

30. Ibid., pp. 198-230.

31. These notions are elaborated in Giddens's The Constitution of Society: Outline of the Theory of Structuration (Berkeley: University of California Press, 1984), in which he develops the idea of localization, pp. 110-161.

32. Advocates of an orthodox version of Marxism assert that collective action is motivated by class-based interests that arise from the given economic circumstances. This focus on the economic sphere neglects people's own involvement in structuring interests and affecting the economic situation in which they find themselves. Recent attention to the labor process has helped to qualify the overly deterministic explanation of how the relation to the means of production influences class consciousness. 
this perspective, I have sought to problematize the question of class action by emphasizing the structures by which work and neighborhood or work and households are connected or set apart. ${ }^{33}$ An examination of the changing interrelationship among the three loci of work, neighborhood, and household over the course of economic and political turns will, I suggest, throw light on the question of why servants rarely identified themselves in class terms.

Domestic servants are workers like other workers. They all sell their labor power in return for wages. Yet the domestic servant is more "special" than, say, the miner or factory worker. The labor process in domestic service differs in important respects from that in a larger enterprise where laborer and employer rarely meet in person and compliance with the requirements of the job is achieved through a technical division of tasks carried out in a routine pattern and through scientific management. ${ }^{34}$ In the interpersonal labor process in domestic service compliance is created through direct supervision. Although legal rules may exist concerning terms of work, they are rarely applied, certainly not in Zambia. The employers decide how to deal with their servants by judging their personal qualities rather than their skills and/or efficiency.

The labor process in domestic service is hierarchical, asymmetric, and deeply charged with idiosyncratic factors. The privatized nature of the job, its special locus in the employer's household, where most servants labor in isolation from other workers when on duty, do perhaps accentuate a servant's sense of personal dependence on the employer's goodwill. This sense in turn may adversely affect the servant's experience of sharing identity with other workers, particularly if he or she resides on the employer's property in a high-income residential area, further distanced from the mass of ordinary workers. The peculiar personalness of the relationship between worker and employer in domestic service, the special nature of the work, which produces use value rather than exchange value, and the odd living

33. For Western examples of this approach, see C. Calhoun, The Question of Class Struggle: Social Foundations of Popular Radicalism during the Industrial Revolution (Chicago: University of Chicago Press, 1982), and I. Katznelson, City Trenches: Urban Politics and the Patterning of Class in the United States (New York: Pantheon, 1981). For African examples, see the contributions to Frederick Cooper, ed., Struggle for the City: Migrant Labor, Capital, and the State in Urban Africa (Beverly Hills, Calif.: Sage, 1983), and for South Africa, Belinda Bozzoli, ed., Town and Countryside in the Transvaal: Capitalist Penetration and Popular Response (Johannesburg: Ravan Press, 1983).

34. There are several different types of control over industrial workers on the job and a rich literature on the forms such controls take and why. The works of Harry Braverman, Labor and Monopoly Capital: The Degradation of Work in the Twentieth Century (New York: Monthly Review Press, 1974), and Michael Burawoy, Manufacturing Consent: Changes in the Labor Process under Monopoly Capitalism (Chicago: University of Chicago Press, 1979), infused this field of research with new vigor. A useful source is $\mathrm{R}$. Edwards, Contested Terrain: The Transformation of the Workplace in the Twentieth Century (New York: Basic Books, 1979). 


\section{Introduction}

arrangement combine to put servants in an ambiguous situation vis-à-vis other segments of the working class. The interpersonal aspect and domestic nature of this labor process also mark the experience of work as a private one. Since the work experience is rife with ambiguities and troubles, it becomes difficult to talk about it objectively, that is, discursively in Giddens's terms, perhaps because the participants are too close to their material.

Most servants in Zambia today seek from their jobs only the money and the housing that often comes with the job. They have few illusions about acquiring benefits that might improve their prospects for upward mobility. The perks are too few and insignificant in an economy with runaway inflation, and their skills derived from labor-intensive toil are hardly salable in other occupational domains. The question then arises, why do servants consent to carry out a job that reinforces dependency in many situations?

Most servants struggle for tomorrow in two senses: they strive to make a living for themselves and their own household members on a day-to-day basis, and they strain their substandard means in an attempt to ensure that their children never will have to make their living as domestics. On both fronts, servants have to overcome odds that for many are insurmountable. While they all desire to exit from domestic service, few succeed. They all know why, at least at the level of practical consciousness: their job has "no future," they say. Many comply with the demands of the hierarchically structured labor process for fear of losing their meager living, and this they rationalize in practical terms: "Half a loaf is better than none." They also hope that the employers sooner or later will help them. These servants do not, in my view, suffer from a dependency complex as set forth by Octave Mannoni. ${ }^{35}$ When, following Giddens, dependency is counterposed to autonomy, a sense of personal agency is retained. ${ }^{36}$ For even in consenting to the creation and maintenance of their own dependence, servants show themselves as autonomous actors with some power to affect the outcome of their dependent interaction within the employer's household. They com-

35. Octave Mannoni, Prospero and Caliban: The Psychology of Colonization (London: Methuen, 1956). The colonized in Prospero and Caliban perceived the colonizer as a father surrogate to be respected and obeyed, while at the same time he was responsible for his charge. Mannoni's dependence was based on trust that, if the relationship between superior and inferior broke, resulted in feelings of desolation and despair on the part of the colonized (pp. 132-162). For a play, written by a white author in Zambia on this theme, see David Wallace, Do You Love Me, Master? (Lusaka: NECZAM, 1977).

36. A. L. Epstein also qualifies the meaning of trust and dependency in the relationship between colonizer and colonized. See his "Autonomy and Identity: Aspects of Political Development on the Gazelle Peninsula," Anthropological Forum 2 (1970), esp. pp. 431-432, and "Unconscious Factors in the Response to Social Crisis: A Case Study from Central Africa," in The Psychoanalytic Study of Society, vol, 8 (1979), pp. 3-39. 
ply, but within limits. If the work situation becomes intolerable and if they find better avenues, they make the ultimate autonomous decision: they quit.

Servants' behavior while at work is thus shaped not only by the demands placed on them there but also by processes beyond the workplace, principally those that relate to their own households and the changing needs of its members. Some of these extrawork forces are influenced by cultural practices, others by associations with neighbors, fellow workers, people in other lines of work, and friends and relatives. Servants thus have conflicting interests that all affect how they perceive their place in Zambia's evolving class structure. The interests that a servant feels an identity with may change over time and they may be different for men and women. They may vary with the servant's familial status and length of domestic employment, so that a long-time servant who is the head of a household may identify the locus of his or her interests in a different way from one who is young, unmarried, and relatively new to domestic service.

\section{The Making of Gender}

So far, I have taken my actors as given: servants and their employers. But at the turn of the last century in Zambia there were no givens. When a small white population had settled and gradually began to grow, and in the process felt the need for workers to do the dirty and time-consuming work involved in creating and maintaining households without amenities, there was no ready pool of domestics willing and able to perform household service. There certainly was no script in which roles, gestures, and routines had been laid out in advance, although employers used their experience of servant-keeping at home in their dealings with Africans in the new territory. Persons of African background had to be made into servants in a manner that had much in common with the domestication of wild animals. They were considered "raw," and even today, some employers speak of "breaking in" their servants.

The resulting social practices were structured not only in terms of class and power, but also by gender. Initially, and for a long time, these servants were not women, but men. Employers in Northern Rhodesia, far from taking women servants for granted, avoided them. For reasons I discuss at length later, many continue to do so today.

Most recent studies of domestic service have emphasized the central involvement of females in such work and have, consciously or not, applied a biological metaphor to explain the subordination a servant experiences in the social relations that structure the household and the wider society. In a felicitous argument, Karen Sacks has pointed out that the biological meta- 
phor is part of the anthropological research tradition. ${ }^{37}$ Yet the discipline of anthropology does not hold the droit de seigneur on this thinking. It is prevalent in the other social sciences and shared among broad segments of society who tend to think of gender as a product of biological differences that set women and men apart. Such a view has prompted many scholars of domestic service to use the nineteenth-century domestic service pattern in the West to universalize the present situation and thereby underestimate its singularity. ${ }^{38}$ The result is a contrasting and stressing of presumably given differences between women and men, rather than the raising of questions about how such differences themselves are created. For gender roles are not given. They are made, and created as a result of women's and men's changing social and economic experiences. The gender division of labor is socially constructed. How, when, and why its slots are allocated to the two sexes become issues for investigation rather than questions to which biological "nature" supplies ready-made answers.

Zambia provides an interesting setting in which to explore how gender roles are made and changed. I do so by asking questions about how employment practices were routinized in the opening decades of this century and how they become institutionalized in the longer term, even while at times being remade in different forms and undergoing changes. The employment practice at issue is the preference for the male servant, which persists to the present day, and its reverse, the reluctance to employ women as servants.

\section{Domestic Service: Literature and Scholarship}

I noted above that till fairly recently, domestic service remained a relatively unexplored domain in scholarship in the West and in the Third World. The nature of the occupation itself helps to explain its invisibility, and shifts in social science interests suggest reasons for the more recent proliferation of studies on domestic service. ${ }^{39}$

In northwestern Europe and North America, live-in domestic service

37. Karen B. Sacks, Sisters and Wives: The Past and Future of Sexual Equality (Urbana: University of Illinois Press, 1982), pp. 24-64.

38. This is a slightly changed paraphrase of M. Z. Rosaldo's description of how nonanthropologists are misusing anthropological data, in "The Use and Abuse of Anthropology: Reflections on Feminism and Cross-Cultural Understanding," Signs 5 (1980): 389-417.

39. Some of the most well known of these studies are: Leonore Davidoff, The Best Circles: Society, Etiquette and the Season (London: Croom Helm, 1973), Jean J. Hecht, The Domestic Servant Class in Eighteenth-Century England (1956; London: Routledge and Kegan Paul, 1980); David M. Katzman, Seven Days a Week: Women and Domestic Service in Industrializing America (New York: Oxford University Press, 1978); Horn, Rise and Fall; and McBride, Domestic Revolution. 
has indeed declined as a major occupational domain for women. When women replaced men as servants toward the end of the eighteenth century, they tended to be young, from rural backgrounds, poorly educated, and unmarried. At this time the decline of household production was eliminating the economic role for unmarried women at home and the urban economy offered them little else than low-paid jobs as household servants. Live-in domestic service was something many such young women expected to do for a while but not to engage in as a lifetime occupation. They hoped, as do women in Zambia today, to marry, preferably men of slightly better means than their own fathers and then to establish their own households. The fate of Samuel Richardson's Pamela illustrates the scenario: the dowryless servant girl marries her rich master, thus solving her problem of how to make a living..$^{40}$ Domestic service was not considered a particularly nice job, and what official census figures we have on this occupation in Europe and North America in the past are likely to underreport the actual numbers of servants: domestics might have been reluctant to admit the nature of their occupation to census takers. In the United States, where few nativeborn American women made themselves available as live-in domestic workers, newly immigrant European women were typically drawn into service, and many married "up." 41

But domestic service has not disappeared as an important occupational domain for women in late twentieth-century America. When white women left domestic service, it remained an occupational venue for minority women. For historical reasons such as slavery, and because of continued discrimination in the labor market by race and sex, poorly educated black American women never left domestic service. Abolition exchanged domestic slavery for contractual servitude, and black American women have persisted in domestic service along with its transformation from live-in to day work. ${ }^{42}$ The upward mobility thesis had little relevance to their living and working experience in a class-structured society with deep de facto racial divisions. ${ }^{43}$ Neither they nor the later additions of minority women-for

40. Samuel Richardson, Pamela: Or Virtue Rewarded. In a Series of Familiar Letters from a Beautrful Young Damsel to Her Parents (London: Harrison and Company, 1785).

41. Janice Reiff Webster, "Domestication and Americanization: Scandinavian Women in Seattle, 1888 to 1900," Journal of Urban History 4 (1978): 275-290; Stephen Steinberg, "Why Irish Became Domestics and Italians and Jews Did Not," in his The Ethnic Myth: Race, Ethnicity, and Class in America (New York: Atheneum, 1981); and Daniel E. Sutherland, Americans and Their Servants: Domestic Service in the United States from 1800 to 1920 (Baton Rouge: Louisiana State University Press, 1981).

42. On this point, see Judith Rollins, Between Women: Domestics and Their Employers (Philadelphia: Temple University Press, 1985); and Katzman, Seven Days.

43. Evelyn Nakano Glenn, Issei, Nisei, War Bride: Three Generations of Japanese American Women in Domestic Service (Philadelphia: Temple University Press, 1986); and Rollins, Between Women. 


\section{Introduction}

example, Chinese, Japanese, Mexican, Central American, and Caribbean-to the army of day-working domestics in the United States can expect much upward mobility in today's shrinking economy. As in the past, many of today's domestics remain uncounted, and we have little substantive knowledge about the nature of this occupational domain today. ${ }^{44}$

The upward mobility thesis, derived from the experience of one segment of women domestics during an expanding phase of the West's economic history, has been exported to the developing world, where, with a few exceptions, it has been useless. ${ }^{45}$ In general, few studies have been undertaken of domestic service in the Third World. Most of the existing work concerns Latin America, where most servants are young migrant women from rural backgrounds. They have been described as moving through a series of gradually better-paying service jobs that serve as a route up. ${ }^{46}$ But while there still are many women domestic servants, their occupation appears to be declining as a major urban employment source in many Latin American cities. ${ }^{47}$ Studies from India show a somewhat different situation, as does the available information on domestic service from China and Malaysia. ${ }^{48}$ In all these cases, cultural factors complicate the employment relationship. The Indian situation, for one, is complex because of the division of labor embodied in the caste system. Extraeconomic factors structure work recruitment, determining which caste as well as which sex may perform which tasks for whom. An exception occurs in the recruitment of Christian servants, both women and men, in a manner perhaps neutral to the religious and gender terms of the caste system. In the state of Kerala, unmarried Christian girls from poor rural backgrounds seem to be preferred as domestic servants in many affluent urban Christian households, where they work for varying lengths of time before returning to marry in

44. Shellee Colen, "With Respect and Feelings': Voices of West Indian Child Care and Domestic Workers in New York City," in All American Women: Lines That Divide, Ties That Bind, ed. Johnetta Cole (New York: Free Press, 1986), pp. 46-70.

45. The main proponent of this thesis is Chaplin,"Domestic Service."

46. For example, Emily M. Nett, "The Servant Class in a Developing Country: Equador," Journal of Inter-American Studies 8 (1966): 437-452, and work by Margo L. Smith, e.g., "Domestic Service as a Channel of Upward Mobility for the Lower-Class Woman: The Lima Case," in Female and Male in Latin America, ed. Ann Pescatello (Pittsburgh: University of Pittsburgh Press, 1973), pp. 191-207. Ximena Bunster and Elsa M. Chaney qualify this view in Sellers and Servants: Working Women in Lima, Peru (New York: Praeger, 1985).

47. This is indicated by Harley L. Browning, "Some Problems of the Tertiarization Process in Latin America," in Urbanization in the Americas from Its Beginnings to the Present, ed. Richard P. Schaedel et al. (The Hague: Mouton, 1978), p. 160.

48. Papers presented to symposium on domestic workers at the Eighty-fourth Annual Meeting of the American Anthropological Association Washington, D.C., December 4-8, 1985, bear this out. Among them, M. Jocelyn Armstrong (University of Illinois), "Female Domestics in Industrializing Malaysia," and Rubie S. Watson (University of Pittsburgh), "Domestic Workers: Wives, Concubines, and Maids in Chinese Society." 


\section{Introduction}

the rural areas. ${ }^{49}$ Domestic service is a socializing experience, but this case illustrates the irrelevance of such knowledge outside of the employing household. The women were unable to transfer their work-related experience so as to move beyond their original position in the social structure.

Aside from the Latin American cases just referred to, none of the nonWestern studies of domestic service supports the upward mobility thesis. The thesis ignores the critical role that race and ethnicity can play in structuring relations in production. That role is exemplified in black American and other minority women's continued experience in domestic service in the United States. It is also illustrated by the countries of eastern and southern Africa, particularly during the colonial period and in the Republic of South Africa today, where race and sex were primary factors in the state's structuring of roles in production.

The existing studies of domestic service in Africa pertain almost exclusively to the southern region. ${ }^{50}$ The remainder consists largely of descriptions done offhandedly in the context of studies with different focuses across the African continent. Recently, several studies, particularly from West Africa, have highlighted the role of young female relatives in performing household work without pay. ${ }^{51}$ Commonly referred to as fostering, this practice is a research topic in its own right - and I shall have something to say about the Zambian variety in the main body of this book.

The South African studies offer a kaleidoscopic story of women of all races and men passing through domestic service. ${ }^{52}$ After the abolition of slavery in 1834, poor Afrikaaner women and British women brought over from Europe worked as domestics in white households. As members of household staffs consisting mainly of African men, these white women's

49. V. Tellis-Nayak, "Power and Solidarity: Clientage in Domestic Service," Current Anthropology 24 (1983): 67-79.

50. Among the chief studies are Michael G. Whisson and William Weil, Domestic Servants: A Microcosm of "The Race Problem" (Johannesburg: Institute of Race Relations, 1971); Eleanor Preston-Whyte, "Race Attitudes and Behavior: The Case of Domestic Employment in White South African Homes," African Studies 35 (1976): 71-89; special issue on domestic labor of the South African Labour Bulletin 6 (1980); Jacklyn Cock, Maids and Madams: A Study in the Politics of Exploitation (Johannesburg: Ravan Press, 1980); and Suzanne Gordon, A Talent For Tomorrow: Life Stories of South African Servants (Johannesburg: Ravan Press, 1985).

51. Roger Sanjek, "Maid Servants and Market Women's Apprentices in Adabraka," paper presented to symposium on domestic workers at the Eighty-fourth Annual Meeting of the American Anthropological Association, Washington, D.C., December 4-8, 1985; Enid Schildkrout, "The Fostering of Children in Urban Ghana: Problems of Ethnographic Analysis in a Multi-Cultural Context," Urban Anthropology 2 (1973): 48-73; and "Age and Gender in Hausa Society: Socio-Economic Roles of Children in Urban Kano," in Sex and Age as Principles of Social Differentiation, ed. Jean S. LaFontaine (London: Academic Press, 1978), pp. 109-138.

52. Cock, Maids and Madams. 


\section{Introduction}

presence proved problematic, and they were replaced by African men soon after the turn of the century. African men persisted in domestic service on the Witwatersrand till the late 1930s, but were replaced by coloured and Affrican women in the Cape much earlier. ${ }^{53}$ With growing demands for African labor in the mines, women gradually became more numerous in this occupation also on the Witwatersrand. Today in South Africa domestic service is considered an African woman's job, and it remains a life-long occupation through which married and unmarried women as well as single mothers pursue a series of deadend jobs. ${ }^{54}$ In white-dominated Rhodesia, domestic service remained a male preserve longer than in South Africa. ${ }^{55}$

The vexations that reflect the difficulty of maintaining difference between servant and employer within the household have been captured forcefully by the literary imagination. Indeed, novelists and writers have had more to tell us about the nature and nuances of the servant-employer relationship than have social scientists. Servants and their employers have been recurrent figures in European, North American, and African literature. The literary writer's servant is there in an active variety: as loyal tool, mercenary opportunist, active agent, disturber of the social order, representative of the rising bourgeoisie, forerunner of the revolution. As a metaphor the figure of the servant has been used to highlight intimate psychosexual power relationships, to represent the African oppressed, as a symptom of nationalist awakening, or as a yardstick against which the health or sickness of postcolonial African society is measured. ${ }^{56}$ African writers, black and white, have used the figure of the servant for all of these things, yet not exactly in the same manner. In several works by black writers produced in Zambia, servants do figure, though not prominently. Domestic employment is just one detail in the context of the lives of the main characters. ${ }^{57}$

53. Charles van Onselen, "The Witches of Suburbia: Domestic Service on the Witwatersrand, 1890-1914," in van Onselen, ed., Studies in the Social and Economic History of the Witwatersrand 1886-1914 (London: Longman, 1982), vol. 2, New Nineveh, pp. 1-73; Deborah Gaitskell, Judy Kimble, Moira Maconachie, and Elaine Unterhalter, "Race, Class, and Gender: Domestic Workers in South Africa," Review of African Political Economy 27/28 (1984): 86-108.

54. Eleanor Preston-Whyte develops this point in "Families without Marriage: A Zulu Case Study," in Social System and Tradition in Southern Africa: Essays in Honour of Eileen Krige, ed. John Argyle and Eleanor Preston-Whyte (Cape Town: Oxford University Press, 1978), pp. 55-85.

55. Duncan G. Clarke, Domestic Workers in Rhodesia: The Economics of Masters and Servants (Gwelo: Mambo Press, 1974), and chapters on servants and their employers in A. H. K. Weinrich, Mucheke: Race, Status, and Politics in a Rhodesian Community (New York: Holmes and Meier, 1976).

56. Stewart Crehan, "Master and Servant: A Comparative Literary Survey," mimeographed paper presented at the University of Zambia, n.d.

57. Andreya Masiye, Refore Dawn (Lusaka: NECZAM, 1970); Grieve Sibale, Retween Two Worlds (Lusaka: NECZAM, 1979); and Gideon Phiri, Victims of Fate (Lusaka: NECZAM, 1972). 


\section{Introduction}

Taking the literature from the southern Africa as my example, there are differences in the way black and white writers construct the servant's viewpoint. Doris Lessing and Nadine Gordimer, writing on Southern Rhodesia and South Africa respectively, have offered acutely sensitive and at times shocking descriptions of the domestic service institution. ${ }^{58}$ But few writers have surpassed Ezekiel Mphalele's "Mrs. Plum." 59 This story gives voice to the African woman servant, depicts the economic and interpersonal situation that emerges in the servant-keeping context, and highlights that servants, despite all odds, retain some power in the relationship. Since the writer's imagination often captures popularly shared sentiments that are rarely part of the official discourse, insights gained from literary works on domestic service may be brought to bear creatively on more conventional social science analysis.

Why has this particular occupational domain received so little scholarly attention? Since they rarely formed a class in objective and subjective terms, servants might have been invisible to those labor historians who have viewed labor mobilization and strikes as the chief evidence of class. Defining class in such terms would tend to eliminate servants from the terrain of class analysis proper, for they often appeared uninvolved in the political arena. Servants may have been ignored by mainstream social scientists because they have considered domestic labor to be women's work, and for a long time they saw no need to problematize or raise questions about its agents. But domestic service has had a long history in the West as a typical man's job-and in some parts of the world is still thought to be so. Thus we must look farther than gender for an explanation of why the occupation was for so long neglected by scholars.

I suggest that the additional reason concerns the special nature of the labor process in domestic service. As the subordinate actors in a hierarchically structured work relationship, servants rarely spoke freely. Although they were conspicuously present in wealthier households, servants were rendered virtually "absent" by the social practices that became routinized in household work. Most of what we know about servants is expressed in the discourse of their employers. With some interesting exceptions, servants have left few personal records. ${ }^{60}$ In their efforts to make

58. Servants figure frequently in the writings of these two authors and are among the key actors in Lessing's The Grass Is Singing (London: M. Joseph, 1953), and "A Home for the Highland Cattle," in her Five: Short Novels (London: M. Joseph, 1953); and Gordimer's "Ah, Woe Is Me" and "Happy Event," in her Selected Stories (London: Jonathan Cape, 1975), and July's People (New York: Viking Press, 1981).

59. Ezekiel Mphalele, "Mrs. Plum," in his In Corner B (Nairobi: East African Publishing House, 1967).

60. These exception include Peter Beard, collector, Longing for Darkness: Kamante's Tales from Out of Africa, with Original Photographs (January 1914-July 1931) and Quotations from Isak Dinesen (New York: Harcourt Brace Jovanovich, 1975); Liz Stanley, ed., The Diaries of Hannah Cullwick, Victorian Maidservant (London: Virago Press, 1984); and Hans 


\section{Introduction}

servants visible, scholars have had to tease information out of their employers' letters, diaries, and biographies, to read between the lines of travel descriptions, in addition to sifting through employment data and legal records. These data have already been edited in the recording process and from them we are most likely to glean a flat, stereotyped description of servants which lacks a sense of life.

Studies that make use of oral history data and "life histories" capture a better sense of lives and active interaction. This methodology is central to much recent research in social history. ${ }^{61}$ I see the recent proliferation of domestic service studies as a part of this effort and concern to capture the lived experience of ordinary women and men, the ways in which their activities contributed to maintaining as well as to changing the societies in which they lived. A parallel concern has fueled recent scholarship in African history, which has sought to demonstrate the results of African initiative in the face of repressive colonial economic and political structures and of continued postcolonial dependency relationships. ${ }^{62}$ To tease out the African voice requires ingenuity and imagination, for if the West is poor in terms of conventional records on ordinary people, Africa is even more so.

Drawing on interdisciplinary insights, I explore in this book how domestic service in Zambia historically and at the present time came to be taken for granted as a perquisite of social and economic position. I suggest that the occupation in that country is developing its own trajectory, which is not a delayed repetition of patterns found elsewhere. To explain the difference I reckon with the critical roles of race and sex in structuring relations of production during the colonial period and of class and sex during the postcolonial period. I have attempted to clarify how and why the African woman's gender role was fabricated in such a way that she was excluded from most urban wage labor, particularly domestic service. Economic, demographic, and political factors shaped the gender division of labor in domestic service, but so did cultural and ideological factors. These factors, in slightly altered configurations, continue to do so in Zambia today. In my comparative discussion of late twentieth-century dynamics in paid household work, I seek to bring my findings from Zambia to bear on developments closer to home. Today, it seems everybody in the United States wants relief from housework. I seek to make sense of this resurgence of

C. and Judith-Maria Buechler, Carmen: The Autobiography of a Spanish Galician Woman (Cambridge, Mass.: Schenkman, 1981). To this list might be added Elsa Joubert's recording of Poppie's story, The Long Journey of Poppie Nongena (Johannesburg: Jonathan Ball, 1980).

61. Oliver Zunz, ed, Reliving the Past: The Worlds of Social History (Chapel Hill: University of North Carolina Press, 1985).

62. William Beinart and Colin Bundy, Hidden Struggles in Rural South Africa: Politics and Popular Movements in the Transkei and Eastern Cape, 1890-1930 (Berkeley: University of California Press, 1987), and Cooper, ed., Struggle for the City. 


\section{Introduction}

interest by relating the forces that have recreated the need for paid household workers in our contemporary economies to world economic developments. Household work, whether paid or not, is a critical economic domain, and this study challenges us to do more research on the ways it articulates with other occupational avenues over the course of local and worldwide economic booms and busts. 
